\title{
Domestic and External Neomercantilism in the American Sanctions on Qaddafi's Libya
}

\author{
Ahmed Mahdi \\ Lecturer, Political Science \\ The British University in Egypt (BUE)
}

\section{Abstract}

In 2003, Libya suspended its weapons of mass destruction program after years of American and international sanctions. The literature concerning this issue has focused on the debate about which type of American policy tool has had the biggest role in Libya's surrender, whether it was economic sanctions, military coercion, or diplomacy. However, the literature ignores explaining the American-Libyan relations policy in terms of International Political Economy (IPE) theory. Focusing on the IPE theory of neomercantilism, this paper argues that the definition of neomercantilism allows a variation between a minimalist definition and a maximalist definition for neomercantilism, as well as a variation between what could be called domestic neomercantilism and external neomercantilism. Furthermore, the paper argues that this variation allows neomercantilism to offer a sound explanation of American policy towards Libya during the sanctions period. The assumptions of neomercantilism are tested against the events of the Washington-Tripoli relations during this period.

Keywords: Neomercantilism, sanctions, Libya, the United States 


\section{Introduction:}

American oil companies have been investing in Libya's oil sector during the era of King Idris As-Senussi, before the revolution led by Moammar Qaddafi in 1969. Since then, Qaddafi adopted an anti-Western and anti-American agenda. The United States started to regard Libya as a rogue, terrorist-sponsoring state since Washington accused Tripoli of orchestrating the La Belle discotheque bombing in Berlin in 1986, which led US President Ronald Regan to order the bombing of Tripoli a few days later. This was followed by the Pan Am Flight 103 bombing over Lockerbie in December 1988, where the West accused Libya of implementing this attack on a civilian flight. These events led to various American and UN sanctions imposed against Libya. UN sanctions were suspended following the Libyan surrender of two Libyan intelligence agents suspected of carrying out the Lockerbie bombing in 1999, but American sanctions remained in place ("UN Lifts Sanctions Against Libya", 1999). The sanctions on Libya continued until, in December 2003, Tripoli announced that it would quit sponsoring terrorism and that it would surrender its weapons of mass destruction program.

\section{Objective 1:}

This paper argues that Washington has followed a neomericantilist policy in these sanctions on Libya. Neomercantilism is a mainstream theory in International Political Economy (IPE), where the state is the main actor on the international stage. Other aspects of neomerantilism include that the security and political considerations of the state have priority over the economic and corporate profit considerations, and that dealings between states reflect a zero-sum game or a security 
dilemma, where one state's gain is another state's loss, or where one state is more secure when the other state is under threat. Nevertheless, works by different authors and experts show that the definition of neomercantilism does allow some flexibility, which might forego a strict adherence to these characteristics in favour of a more minimalist definition, as will be shown below. Therefore, this paper argues that the definition of neomercantilism may oscillate between a minimalist definition, and a maximalist definition.

$\mathrm{H}_{1}$ : The definition of the IPE theory of neomercantilism allows a variation between a minimalist definition and a maximalist definition.

This hypothesis would be supported by presenting the writings of different experts on political economy. These writings would show different, but arguably correct, usages of the term "neomercantilism" in different policies adopted by different countries, where the common factor in all of these writings is the strong role of the state in political and economic life.

\section{Research Problem:}

However, there is surprisingly little literature which deals, in depth, with neomercantilism in modern American foreign policy, especially in dealing with cases of economic coercion. (Most of the works which deal with neomercantilism in American politics focus on the eighteenth and early nineteenth century America, especially the policies of Alexander Hamilton. Academic works which deal with neomercantilism in modern American foreign policy only do so in passing.) There is also a dearth in the literature which deals 
with economic sanctions, and economic coercion in general, as neomercantilist phenomena.

\section{Objective 2:}

It is the purpose of this paper to fill this gap, and to focus on the neomercantilist nature of American sanctions on Libya as a form of economic coercion, which successfully achieved its target and made Qaddari comply with the American will in 2003.

$\mathrm{H}_{2}$ : The United States has followed a neomercantilist policy in its policy towards Libya during the sanctions period.

To support this hypothesis, three research questions will be tackled to examine the American policy towards Libya. Libya is chosen as a case study, since Libya is one of the most giaring examples of the difference between the coercer's policy towards the target state before the target state complied with the will of the coercer, and the coercer's policy after the target state complied. To use Drezner's words, Libya's 2003 surrender of its WMD program is "the exemplar case" of the success of sanctions (Drezner, 2011, p. 103).

\section{Methodology:}

The common thread in all of the definitions and uses of the term "neomercantilism", (or, one can say, the main feature, or main definitional component, of neomercantilism) is the main role of the state vis-à-vis the domestic economic or business institutions. To properly test for neomercantilism, the extent of the role of the state should be examined: 
$Q_{1}$ : To what extent was the American government the main actor in the US policy towards Libya?

Another main feature of neomericantilism is the zero-sum mentality, the view that one side's loss is the other side's gain. This is also tested:

$Q_{2}$ : Did the US policy towards Libya reflect a zero-sum game, where one state's gain is another state's loss?

The third main feature of neomercantilism is the prominence of the state's security and strategic interests over the interests of the business corporations and the economy in general. This requires an extent of state influence (or, in certain cases, full control) over the actions of the domestic economic and business institutions:

$Q_{3}$ : To what extent did security and geopolitical considerations have priority over energy and other economic considerations in the US policy towards Libya?

Based on the questions above, I offer the argument that the definition of neomercantilism could be divided into what I call "domestic neomercantilism" and "external neomerantilism", as further illustrated below.

First, I introduce what I call "domestic neomercantilism" which deais with the state's role and the relation between the state and the domestic economic or business institutions. This can be divided into different degrees, or different levels, as follows. First, the least common denominator in all definitions of "neomercantilism", which is a large role for the state (the minimalist definition). This is followed by a higher level of domestic neomercantilism, which is a protective role for the state towards the domestic economy. 
The next level of domestic neomercantilism is a coercive role for the state against domestic economic/business firms which do not abide by the state's will. The final and highest level is full state control over the domestic economic/business firms (the maximalist definition). Each level will be explained in more details later.

Second, I introduce what I call "external neomercantilism" which tackles the dealings of the state towards other states on the international arena. This is characterized by a zero-sum mentality where one state's loss is the other state's gain.

\section{Research Plan:}

To support my hypotheses, this paper is divided as follows. The next section presents a theoretical framework of neomercantilism as a mainstream theory of IPE. The following section will present the literature review of the Libyan surrender to the American sanctions in December 2003. This is followed by a historical background of the events which took place between Washington and Tripoli during the George W. Bush Administration (2001 2009), then a section for the application of my classification of the definitions of neomercantilism to the Libyan case.

1- Theoretical Framework: The different definitions of Neomercantilism:

\section{Classic versus neo mercantilism:}

Before discussing the idea of neomericantilism, one has to first tackle the classic version of mercantilism. Mercantilism was a theory and/or policy which was applied in the context of the geopolitical competition between the European powers between 
the sixteenth and eighteenth centuries. Being in a strategic competition, each state had to accumulate as much bullion (gold and silver) as possible to help it build a powerful army to help it fight against other European powers. To accumulate this vast amount of bullion, the state had to achieve a trade surplus and a positive balance of trade against the other European powers. Within this zero-sum mentality, the government in each state played a role in supporting its merchants to export more than they import and to accumulate as much bullion as possible, and to acquire more bullion than their rivals (the other European states).

There have been several writings on the differences between the classic form of mercantilism (described above) and its modern version; "neomercantilism". Kirshner (1999) argues that the difference is in timing, as neomercantilism applies to the theory and practice of mercantilism after Adam Smith's The Wealth of Nations was published in 1776. Since then, pioneering neomercantilist thinkers (like Alexander Hamilton and Frederich List) have accepted some of Adam Smith's writings on free trade, and incorporated them into their own neomercantilist policies and thoughts (Kirshner, 1999, p. 70).

Gilpin (1975b) argues that classic mercantilism focused on the accumulation of bullion and the balance of payments surplus, while neomercantilism "can take many forms in the contemporary world", including trade surplus, import or export controls, the expansion of world market shares, preponderance in technology and other forms of economic power (Gilpin, 1975b, p. 46-45). 


\section{Minimalist versus maximalist forms of neomercantilism:}

Gilpin has also defined neomercantilism in terms of an imposing or dominating role of the state and the subordination of other economic or business institutions. One definition he has offered for neomercantilism was "the partial subordination of the economy to the perceived security and welfare needs of the state and society". Neomercantilism, therefore, is "the striving for security by economic means" (Gilpin, 1977, p. 28). The "essence" of neomercantilism, argues Gilpin, is "the subservience of the economy to the state and its interests - interests that range from matters of domestic welfare to those of international security" (Gilpin, 1975a, p. 25). In other words, according to Gilpin, neomercantilism is "the attempt of government to manipulate economic arrangements in order to maximize their own interests, whether or not this is at the expense of others. These interests may be related to domestic concerns (full employment, price stability, etc.) or to foreign policy (security, independence, etc.)" (Gilpin, 1975b, p. 45).

In his analysis of Saudi oil policy during the global oil price war between OPEC, Russia and the United States between 2014 and 2016, Mahdi (2020) offers what he calls the three "definitional components" of neomercantilism. Based on Cohn (2016) and others, Mahdi offers three definitional components of neomercantilism. First, the state is main actor in international relations. Second, security and geopolitical considerations have priority over economic and business profit considerations. Third, relations between states are based on a zero-sum game. Mahdi has characterized the differences between neomercantilism and liberalism as follows: 
Neomercantilism believes in power politics, while liberalism believes in peaceful cooperative relations... Liberalism believes that the state is giving up some of its sovereignty to the corporations and non-state actors who engage in global economic interaction, and that the state cannot stop this trend. Neomercantilism, on the other hand, believes that the state is controlling the flow of these actors and can stop it if so chooses. Neomercantilism believes that relations between states, including trade and economic relations, are based on zero-sum, relative gains, while liberalism believes that the interaction between states can be a positive sum game where all actors can emerge as winners from the interaction between states (Mahdi, 2020, p. 6).

Apart from Gilpin's emphasis on the "subordination" and "subservience" of the economy to the state's political and strategic interests, many other authors use the term "neomercantilism" more loosely. Much of the literature has used the terms "neomercantilism" to simply imply a policy of a strong government role, government protectionism of the domestic economy, and the use of economic means to achieve political goals. For instance, Kröger (2012) illustrates neomercantilism in Brazil's development policy as "state corporatism" and the use of "economic gains" as means to achieve "increasing national power [through] statism". Lucarelli (2011) argues that Germany is using a neomercantilist policy characterized by "export competitiveness", "export-led growth", "export surplus", which can lead to a series of zerosum, "beggar-thy-neighbour" policies and "retaliatory trade wars". Van Apledoorn (1998) defines the competitive discourse of neomercantilism as: 
Enhancing the global market power of [national] industry against [foreign] competition through government intervention and protectionism. It means being able to compete in the global marketplace by first shielding oneself from the destructive forces of globalization, in order then to enter the fray on the basis of increased strength achieved through nonmarket means.

Japan, in particular, was tackled by several authors for its neomercantilist policies. Beeson (2009) defined neomercantilism in Japan as state interventionism and centralization. Nester (1990) defined Japan's neomercantilism as "a development strategy whereby the state actively intervenes in the economy to bolster strategic sectors with a range of subsidies, import barriers, and export promotion that gives those firms an advantage over their foreign rivals."

Based on the literature above and on the different descriptions of neomercantilism as mentioned above, this paper argues that neomercantilism is divided into two types: "domestic neomercantilism" and "external neomercantilism". The definition of what I call "domestic neomercantilism," which deals with statebusiness relations, can vary along a scale, or a spectrum, which includes the following:

1-A minimalist definition of neomercantilism: State Intervention: This is a definition of neomercantilism where the state's role is only to regulate and plan the general environment in which the business and economic corporations will operate. This is found, for example, in Japan where MITI had a large role in Japan's development planning. 
2- The next level of neomercantilism: State Protection: This is where the state's role goes beyond planning and regulation. The government starts imposing certain supportive and protective measures to protect its domestic industries and businesses. The trade wars where the United States introduces trade barriers to protect its domestic businesses are a good example of this.

3- Then a higher level of neomercantilism: State Coercion, or State Punishment: The state is attempting to have an extent of influence over at least some of the business or economic institutions' behaviour. This includes, for example, preventing the national business or economic institutions from dealing with certain foreign entities or external actors. This applies, for example, in our case of American sanctions on Libya, where the US government imposed laws to punish corporations with deal with the Libyan oil sector.

4-Finally, the maximalist definition of domestic neomercantilism: Full State Control: This is where the government's role goes far beyond planning and protection, and the state has full control or even ownership the means of production. This is found, for example, in state-owned oil and gas companies such as Saudi Aramco (before the IPO), Russia's Gazprom and the Iranian National Oil Company.

Based on the classification above, this paper argues that the American sanctions on Libya satisfied the minimalist definition of neomercantilism; the large role of the state. The American sanctions also satisfied another level of domestic neomercantilism; state punishment or state coercion, since Washington did have a prominent role in protecting the American national security by punishing American firms which dealt with the Libyan oil sector. 
However, these sanctions did not satisfy the maximalist definition of neomercantilism, as Washington did not actually have direct or full control over the behaviour of the American firms (unlike Saudi Aramco or Russia's Gazprom for example, as stated earlier).

The four classifications above (state intervention, state protection, state punishment/coercion, and state control) are four levels of the definition of what I call "domestic neomercantilism", which apply to the state's relations with its own national or domestic businesses and economic firms.

Apart from domestic neomercantilism, there is also the other side of the theory of neomercantilism which deals with the state's external relations with other states. This is what I call "external neomercantilism", which explains a state's external relations, and this is based on the zero-sum mentality of the neomercantilist theory, as one state's gain is another's loss. This zero-sum competition can be over security/political issues, or it can be over economic issues. (See, for example, Leverett, 2008; Mahdi, 2020; Ziegler, 2010).

Thus, I argue that the US sanctions on Libya satisfy both sides of the neomercantilist theory. They satisfy the "domestic" neomericantilist side, especially the third definition, (state punishment or state coercion), where the American government had a prominent role and has issued laws to punish companies which dealt with the Libyan government or the Libyan oil sector. The US sanctions on Libya also satisfied the "external" neomercantilist side, where the American government saw a security threat in Tripoli's support for terrorism and attempt to acquire weapons of mass destruction, and the American sanctions dealt with Libya on that basis. 


\section{II- Literature Review:}

This section will examine the literature on the IPE of sanctions, and the literature on the US sanctions on Libya, and how both suffer from a literature gap in the absence of works which place them both in the context of IPE theory.

\section{A - The International Political Economy of Sanctions:}

Several works tackle the international political economy of economic sanctions. However, these works mainly focus on definitions of "success" or "failure" of economic sanctions, and the reasons which make economic sanctions work or fail. Surprisingly, none of the works goes back to the basics of IPE theory, whether mainstream theories like neomercantilism or neoliberalism, or critical theories like Marxism or other theories.

For example, Drezner's works only focus on the conditions which make sanctions effective, but do not delve into IPE theory. (See, for example, Drezner, 1999; Drezner, 2011; Drezner, 2018). in fact, Drezner expresses his satisfaction that "the gap between policymakers and scholars on economic sanctions is extremely narrow" because "the overwhelming focus of the scholarly literature on economic sanctions has been on whether they work, as opposed to pure theory development" (Drezner, 2018, p. -251 252). However, this does not undermine the importance of placing economic sanctions within IPE theory, which is surprisingly absent in theoretical works. Similarly, Kern has briefly touched upon the protectionist tradition of Alexander Hamilton and Friedrich List (and mentioned the word "mercantilist" only once), but did not make a serious effort to deeply place economic sanctions in IPE theory (Kern, 2009, p. 36). 
In analysing why US firms abide by the sanctions imposed by the US government, Rodman (2001) rejects the neomercantilist school, which says that the US government is able to influence American firms into abiding by government-imposed sanctions at the expense of their own corporate profits. He also rejects the liberal school, which says that, due to globalization and expansion, the US government is no longer able to influence US firms, and that American firms are able to disobey the sanctions imposed by their government to maintain their corporate profits. Rather, argues Rodman, US domestic politics offer a better explanation than both schoois. US firms, he argues, choose to obey US sanctions because of internal or domestic political considerations inside Washington, including fear of legal punishment, and because these firms "rely on the government for federal contracts and for advancing their interests through negotiating market access or debt restructuring." (Rodman, 2001, p. 15). I would maintain that Rodman's thesis, that the firms complied due to fear of Washington's punishment, does not contradict the theory of neomercantilism. On the contrary, based on the spectrum of definitions of "domestic" neomericantilsim, Rodman's argument can actually contribute to one level of neomercantilism which is the level of state coercion or state punishment.

\section{B - US and/or Western Policy Towards Libya:}

This paper uses the US sanctions on Libya as a case study because Libya's surrender in December 2003, to use Drezner's words, is "the exemplar case" of the success of sanctions (Drezner, 2011, p. 103). This is a case when a security threat was perceived, which resulted in sanctions imposed by the American 
government which barred US oil firms from dealing with Libya. When the perceived threat was removed with Libya's surrender of its weapons of mass destruction in 2003, the sanctions were removed and American trade and investment with Qaddafi's Libya proceeded. This is neomercantilism in practice, and a practical application of Gilpin's phrase of "the striving for security by economic means" and "the partial subordination of the economy to the perceived security and welfare needs of the state and society" (Gilpin, 1977, p. 28).

Most of the literature on the US (and Westem) policy towards Libya focuses on the factors which enabled the American/Western sanctions on Tripoli to lead Qaddafi to surrender his weapons of mass destruction program in December 2003. Most significantly, the literature focuses on the debate between coercion and diplomacy. On the one hand, there is the argument that it was mainly coercive diplomacy which had the major role in making Qaddafi surrender his WMD program. (Coercive diplomacy here includes the economic sanctions, the American regime change in Afghanistan and Iraq, and the interception of the cargo vessel $B B C$ China which was carrying equipment for uranium enrichment to Libya). On the other hand, there also is the argument that it was mainly diplomacy and confidence building measures which led Qaddafi to surrender his WMD in December 2003.

Jentleson and Whytock (2005) divide US policy towards Libya into three phases. The first phase (1981-1989) is characterized principally by American sanctions and military force. The second phase (1989-1999) is characterized by more focus on multilateral sanctions by the US and the UN. The third phase (1999-2003) 
is characterized by secret negotiations while Libya was under pressure from sanctions and from US military threat. Jentleson and Whytock use two sets of variables to examine the American and Libyan policies during the three phases. The first set of variables focuses on America's (the coercer state's) strategy. This is measured by three factors: proportionality (the relationship between Washington's demands from Tripoli, and the coercion tools used by Washington against Tripoli), reciprocity (the linkage between Washington's carrots and Tripoli's concessions) and coercive credibility (that Washington should convincingly carry the message to Tripoli that non-cooperation would have negative consequences on Libya). The second set of variables focuses on the vulnerability of Libya's (the target state's) domestic politics and economy to Washington's coercion. They argue that the third phase of US policy towards Libya succeeded at disarming Libya because Washington found the right balance between proportionality, reciprocity and coercive credibility, and because Libya's domestic and economic vulnerability at the time was high. American military coercion was a factor in disarming Libya, but it was not the only factor as it was supported by multilateral economic sanctions and incentives to comply.

Jakobsen (2012) laments that the debate on foreign policy includes only "binary choices between diplomacy or force, economic sanctions or force, engagement or coercion... carrots or coercion." Thus, he recognizes a gap in the "preoccupation with silver bullets" which should "win on their own", and in the fact that "far less attention is paid" to the "relative utility" of different policy tools, or "how different instruments can be used in combination 
to achieve the desired goal" (Jakobsen 2012,p. 490 and passim). He argues that both camps make valid points, but they fall into the mistake of thinking that "carrots and coercion are competing rather than complementary policy instruments." To fill this gap, he offers an "analytical framework which incorporates carrots, coercion and confidence building" (or what he calls the " $3 C^{\prime}$ ) to explain Libya's surrender of its WMD program, arguing that all three components were required to fill such a gap (Jakobsen, 2012, p. 491 and passim). Based on his $3 \mathrm{C}$.model, he examines the effect of US air power, economic sanctions, international isolation, the invasion of Afghanistan and Iraq, Washington's tough stance against rogue states with WMD programs, in addition to American assurances to Qaddafi that sanctions on Libya would be lifted and that no policy of regime change would be implemented against him if he complied. Jakobsen then offers evidence that the correct combination of these American policy tools was vital in Qaddafi's decision to surrender Libya's WMD program.

Stevens (2017) criticizes both of the "normal diplomacy school" and the "coercive diplomacy school" for not giving enough appreciation to the role of military coercion. Stevens (2017) thus argues that the combination of diplomacy and economic sanctions on Libya was not enough, and he offers a model where these two factors were supported mainly by a combination of military coercion plus veiled threats by George W. Bush. This combination of military coercion and veiled threats, which had the main role in forcing Qaddafi to totally surrender his WMD program, came in three forms: Firstly, Bush's regime change in Afghanistan and Iraq. Secondly, testimonies by Secretary of State Colin Powell, 
Secretary of Defense Donald Rumsfeld, CIA Director George Tenet and Undersecretary of State John Bolton that Libya was a terrorism-sponsoring state with weapons of mass destruction and hostilities towards the United States. Thirdly, NATO's interception of the BBC China which carried uranium enrichment equipment to Libya in October 2003.

Unlike Jakobsen (2012) and Stevens (2017), Zoubir (2011) gives some attention to the role of Libya's oil resources, and to the lobbying by US and non-US oil companies to open up investment with Libya. Zoubir also pays attention to the disagreement within the US bureaucracy on policy towards Libya due to lobbying by different groups. On the one hand, the American officials concerned with anti-terrorism, plus American (and non-American) oil companies have lobbied for removing, or at least softening, the sanctions on Libya. On the other hand, the American officials concerned with removing weapons of mass destruction, in addition to the Lockerbie families, pressed for toughening the sanctions on Libya. This, according to Zoubir, led to "mixed signals" being sent from Washington towards Tripoli, especially during the period from 1999 until 2003.

All of the literature above has discussed the political economy of US-Libyan relations, but never attempted to position this political economy in terms of mainstream IPE theory. Thus, this paper is not concerned with evaluating the effectiveness of different American policy tools, or the "who won Libya" debate. Rather, this paper is focused on positioning the US policy in Libya within the neomercantilist school of IPE, and introduces a new classification for neomercantilism to help place the US sanctions on Libya within the neomercantilist and IPE theory. 
The next section will offer a brief historical background of the events before and after Libya's surrender of its WMD program in December 2003.

\section{III- Historical Background}

On Libya, the American president was under pressure from two opposing sides. On the one hand, there was pressure from the relatives of the American victims of the Pam Am Flight 103 which was bombed over Lockerbie in 1988. On the other hand, there was pressure from the American oil companies who were eager to invest in the Libyan oil sector. For example, USAEngage, a Washington-based pro-trade lobby group, said that the sanctions on Libya cost American companies billions of dollars in lost exports every year ("Bush: Libya must accept responsibility"; Lake, 2001; "When will sanctions be lifted").

In 2001, President George W. Bush was facing the decision whether to renew the Iran-Libya Sanctions Act (ILSA) or not. ILSA was signed into law by his predecessor, William J. (Bill) Clinton, in 1996 to impose sanctions on Tehran and Tripoli. The issue of renewing ILSA caused a political battle between two camps. On the one hand, groups like the pro-Israel lobby and the relatives of the Lockerbie victims were in favour of renewing ILSA. On the other hand, the US oil industry argued that the law has had negative effects on American businesses and was a political failure (Watson, 2001). In July 2001, the US Senate extended the sanctions for a further five years, but the Bush Administration argued for a renewal for only two years, in order to give Washington some flexibility to change its policy towards Libya and Iran if necessary ("US Senate extends sanctions law", 
2001). Eventually, however, Bush signed the five-year extension into law in August 2001 ("Libya and Iran hit by new sanctions", 2001).

US-Libyan relations got even tenser following the September 11 attacks. For instance, in May 2002, Washington added Cuba, Libya and Syria to the list of nations which, claimed Washington, were deliberately seeking to obtain chemical or biological weapons. Then-US Under Secretary of State, John Bolton delivered a speech entitled "Beyond the Axis of Evil" at the Heritage Foundation, and said that the three nations could be grouped with Iraq, Iran and North Korea in actively attempting to develop weapons of mass destruction ("US expands axis of evil" 2002). This was despite the fact that Syria, Libya and Sudan quietly offered assistance in the war on terror (Feffer, 2003, p 19; Hardy, 2001). Tripoli has aiso participated in the extraordinary rendition program of flying and interrogating terror suspects.

The Washington-Tripoli relations changed following the Libyan surrender of its WMD program in December 2003. On April 23, 2004, the application of ILSA on Libya was terminated, and the act was renamed the Iran Sanctions Act (ISA) (Katzman, 2006; Katzman, 2007). In 2006, Washington removed Libya from its list of terrorist states, and the US State Department announced that Washington would resume diplomatic relations with Tripoli ("US to renew full ties with Libya").

This change in Libya's position from an enemy to an ally . enabled US companies to invest in the Libyan oil resources, as American companies like ExxonMobil, ChevronTexaco and Occidental started to return to Libya's oil sector ("Major oil 
firms compete for Libya concessions"). In December 2005, tor example, ExxonMobil's subsidiary ExxonMobil Libya Ltd. signed an exploration and production sharing agreement (EPSA) with Libya. In the same month, the Oasis consortium of US firms Amerada Heiss, ConocoPhillips and Marathon Oil signed a deal to return to Libya after their interests there were frozen in 1985 when US sanctions were imposed (Ford, 2006). The Bush Administration supported the efforts of the American oil firms in negotiating with Libya over more deals, as the US became one of the largest purchasers of Libyan oil (Martin, 2006; Zoubir, 2011).

The next section will fit the events discussed above to my theoretical classifications of "domestic neomercantilism" and "external neomercantilism".

\section{IV-Applying the Theory to the Historical Framework:}

I argue that the events presented above do fit, to a certain degree, into "domestic neomercantilism" which tackles government-business relations. They also fit into "external neomercantilism" which deals with the zero-sum nature of stateto-state interactions.

The minimalist definition of what I call "domestic neomercantilism", state intervention, was satisfied. This is a definition of neomercantilism where the state's role is only to regulate and plan the environment in which the business corporations will operate. This definition was satisfied, as the American government was the main actor in imposing the sanctions laws before 2003. After the lifting of sanctions, it was the American government who opened the door for American businesses to deal with Tripoli. Another definition of domestic neomercantilism 
was satisfied: state punishment or state coercion, as the American government threatened the firms which dealt with the Libyan oil sector, and the American firms complied with this threat.

The maximalist definition of domestic neomercantilism, full state control, does not apply here. This is where the government's role goes beyond a certain (but limited) extent of influence over the firms' actions, and the state actually fully controls or even fully owns the means of production. The American government did not have direct or full control over the American oil firms. The firms did comply, however, because of the threat of punishment by the American government to firms which will not abide by American sanctions laws. Rodman's argument that the firms complied due to fear of Washington's repercussions does not contradict the theory of neomercantilism. On the contrary, based on the definitions of domestic neomericantilsim, Rodman's argument can actualiy contribute to one level of domestic neomercantilism, namely, the level of state coercion or state punishment.

The other side of the neomercantilist theory, "external neomercantilism" based on the zero-sum dealings between states on the international arena, was indeed satisfied, as Libya was perceived as a security threat by Washington and therefore sanctions were successfully imposed. Washington gained a security advantage by forcing Tripoli to get rid of its WMD program which would have been a strategic asset for Libya had Tripoli proceeded with it. It was also clear that Washington's security considerations had priority over the economic considerations of investing in Libya's oil.

The events which occurred during the American sanctions 
on Libya, therefore, fit the definitional components of the theory of neomercantilism; the main role of the state, the zero-sum game and the priority of security and political considerations over economic and business considerations.

\section{v-Conclusion:}

This paper has introduced variations to the definition of neomercantilism based on previous uses of the term "neomercantilism". These variations show that the definition of neomercantilism is not as rigid as some scholars have suggested. It is flexible and allows a degree of variety. This variety includes "domestic neomercantilism" and "external neomercantilism", as well as a spectrum between a minimalist definition (government role or intervention) and a maximalist definition (full government control). Neomercantilism applies as long as the government has a significant role in economic or corporate policy.

The fact that neomercantilism was not used to explain sanctions is a significant gap in the IPE literature, as theory is vital to explaining how governments interact domestically and internationally with other state and non-state actors. The four definitions of domestic neomericantilism can help fill the gap. In the American economy, the US government does not have full control over the firms. Yet, the firms comply with the sanctions, even though they are against their business profits, because they are aware of the pressure points that the US government can use against their businesses (as argued by Rodman). This compliance by the firms displays domestic neomercantilism's minimalist definition (government role) and one of the intermediate (government punishment or coercion) definitions, even though 
the maximalist definition (full government control over the firms) is absent. "External" neomercantilism was also evident in the zerosum treatment between Washington and Tripoli over Libya's antiAmerican foreign policy. Washington's security considerations also had priority over the economic considerations of investing in Libya's oil sector.

The four definitions of what I call "domestic" neomercantilism, in addition to what I call "external" neomercantilism, have helped place sanctions within IPE theory, which was absent in the literature. This can be a launching pad for further research over the nature of neomercantilism and the nature of other theories of IPE in dealing with different interactions between different political actors. 


\section{Recommendations:}

Economic sanctions have not been sufficiently analysed using IPE theory, and it is important, for the sake of the discipline, to fill this theoretical gap, by using neomercantilism and other IPE theories to analyse sanctions.

\section{Bibliography:}

\section{Books:}

1. Cohn, T. (2016), Global Political Economy: Theory and Practice. London: Routledge, 2016.

2. Drezner, D. (1999). The Sanctions Paradox: Economic Statecraft and International Relations. Cambridge: Cambridge University Press, 1999.

3. Gilpin, R. (1975a), US Power and the Multinational Corporation: The Political Economy of Foreign Direct Investment. New York: Basic Books, 1975.

4. Kern, A. (2009), Economic Sanctions: Law and Public Policy. New York: Plagrave Macmillan.

5. Rodman, K. (2001). Sanctions Beyond Borders: Multinational Corporations and U.S. Economic Sanctions. Oxford: Rowman and Littlefield Publishers, 2001.

\section{Book Chapters:}

- Drezner, D. (2018). "Chapter 12: Economic Sanctions in Theory and Practice: How Smart Are they?", in Kelly Greenhill and Peter Krause (eds) Coercion: The Power To Hurt in International Politics (Oxford: Oxford University Press): pp. 270-251. 
- Feffer, J. (2003). "Introduction", in John Feffer (ed) Power Trip: US Unilateralism and Global Strategy After September 11 (New York: Seven Stories Press), pp. 27-14.

- Gilpin, R. (1977). "Chapter 2: Economic Interdependence and National Security in Historical Perspective", In Klauss Knorr (ed.) Economic Issues and National Security. (Lawrence: Regence Press of Kansas), pp. 66-19.

- Kirshner, J. (1999) "The Political Economy of Realism", in Ethan Kapstein and Michael Mastanduno (eds) Unipolar Politics: Realism and State Strategies After the Cold War (New York: Columbia University Press, 1999): pp. 102-69

- Leverett, F. (2008), "Resource Mercantilism and the Militarization of Resource Management: Rising Asia and the Future of American Primacy in the Persian Gulf" in Daniel Moran and James Russell, (eds.), Energy Security and Global Politics: The Militarization of Resource Management, Oxford: Routledge, 2008, pp. 242-211.

\section{Academic Journals:}

- Beeson, M. (2009). "Developmental States in East Asia: A Comparison of the Japanese and Chinese experiences", Asian Perspective, Vol. 33, No. 39-5 :2

- Bill, L. (12-2011). "German neo-mercantilism and the European sovereign debt crisis", Journal of Post Keynesian Economics, Vol. 34, No. 2 (Winter 12-2011), pp. 224-205

- Drezner, D. (2011). "Sanctions Sometimes Smart: Targeted Sanctions in Theory and Practice." International Studies Review, Vol. 13 No. 108-96:1. 
- Gilpin, R. (1975b). "Three Models of the Future", International Organization, Vol. 29, No. 60-37:1.

- Jakobsen, P. T. (2012), "Reinterpreting Libya's Turnaround: Bridging The Carrot-Coercion Divide", Journal of Strategic Studies, Vol. 35, No. 512-489:4.

- Jentleson, B. and Whytock, C. (2005), "Who Won Libya? The Force-Diplomacy Debate and its Implications for Theory and Policy", International Security, Vol. 30 , No. :3 66-47.

- Kröger, M. (2012). "Neo-mercantilist capitalism and post2008 cleavages in economic decision-making power in Brazil", Third World Quarterly, Vol. 33, No. 901-887 :5

- Mahdi, A. (2020), "Saudi Neomercantilism in the Oil Price War", Review of Economics and Political Science, Vol. 5, No. 20-2 :1, https://www.emerald.com/insight/content/ doi/10.1108/REPS0134-2019-10-/full/pdf?title=saudineomercantilism-in-the-oil-price-war

- Nester, W. R. (1990) “Japan's Governing Triad: Models of Development and Policymaking", Asian Perspective, Vol. 14 , No. 169-145:1

- Stevens, C. (2017), "The Libyan Debate: Coercive Diplomacy Reconsidered", Diplomacy and Statecraft, Vol. 28 , No. 343-320 :2.

- Van Apeldoorn, B. (1998). "Transnationalization and the Restructuring of Europe's Socioeconomic Order: Social Forces in the Construction of Embedded Neoliberalism", International Journal of Political Economy, Vol. 28, No. :1 53-12. 
- Zoubir, Y. (2011), "The United States and Libya: The Limits of Coercive Diplomacy", The Journal of North African Studies, Vol. 16, No. $297-275$ :2.

- Ziegler, C. (2010), "Neomercantilism and Energy Interdependence: Russian Strategies in East Asia", Asian Security, Volume 6, Issue 1, pp. 93-74.

\section{Government Reports:}

- Katzman, K. (2006), "The Iran-Libya Sanctions Act (ILSA)", The US Department of State, Foreign Press Centres, April 2006,26 , http://fpc.state.gov/documents/organization/66441. pdf).

- Katzman, K. (2007), "The Iran Sanctions Act (ISA)", Foundation of American Scientists, October 2007 ,12, http://www.fas.org/sgp/crs/row/RS20871.pdf.

\section{News Articles:}

- "Bush : Libya must accept responsibility", BBC News, January 2001,31 , http://news.bbc.co.uk/1/hi/world/1145992.stm

- Ford, N. (2006). "US firms back in Libya," The Middle East, (February): 37-36.

- Hardy, R. (2001), "CIA seeks rogue state cooperation", BBC News, October 30, http://news.bbc.co.uk/1/hi/world/ americas.1627988.stm

- Lake, E. J. (2001). "Analysis: Energy report hedges on Iran", May 2001,17 , hitp://web.lexis-nexis.com/executive/ form? index $=e x e c$ en $h t m i \&$ lang $=e n \& u t=3311241244$ 
- "Libya and Iran hit by new sanctions", BBC News, August ,4 2001 http://news.bbc.co.uk/1/hi/world/americas/1473176. stm

- "Major oil firms compete for Libya concessions", Al Jazeera, March 2007,5 , http://www.aljazeera.net/news/archive/ archive?Archiveld $=1034634$

- Martin, J. (2006), "Uncle Sam goes to Libya," The Middle East, (April): 34-30.

- "UN lifts sanctions against Libya", The Guardian, September 2003,12 , https://www.theguardian.com/uk/2003/sep/12/ lockerbie.libya

- "US expands axis of evil", May 2002,6 , news.bbc.co.uk/1/ hi/world/americas/1971852.stm

- "US Senate extends sanctions law", BBC News, July ,26 $2001 \mathrm{http}: / /$ news. bbc.co.uk/1/hi/world/middle east/1457639. stm

- "US to renew full ties with Libya," BBC News, May 2006,15, http://news.bbc.co.uk/1/hi/world/africa/4773617.stm

- Watson, R. (2001). "US may extend Iran Libya sanctions", BBC News, May 2001,24 , http://news.bbc.co.uk/1/hi/world/ americas/1348330.stm

- "When will sanctions be lifted?" BBC News, February ,1 2001, http://news.bbc.co.uk/1/hi/world/1148057.stm 


\section{النظرية التجارية العلديثة الثلاخلية والثخارجية في الثقوبات الأمريكية على ليبيا في عهلها القذافئ.

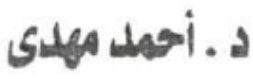 ملرس العلوم السياسية بالجامسة البيريطانية في مصر}

\section{الملاخصن:}

فى عام r...r قامت ثيبيا بالغاء برنامجها لإنشاء أسحة الدمار الشامل بعد أعوام

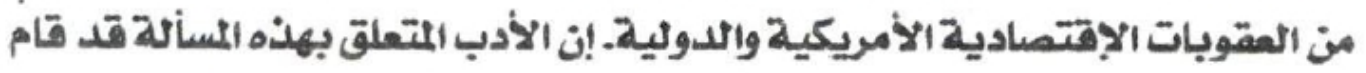

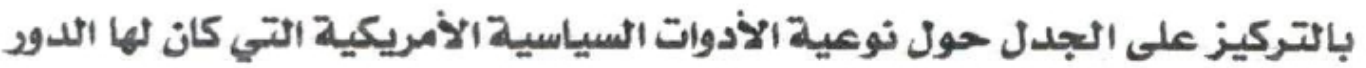

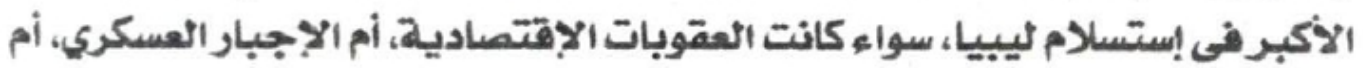

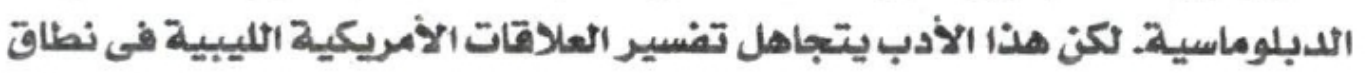

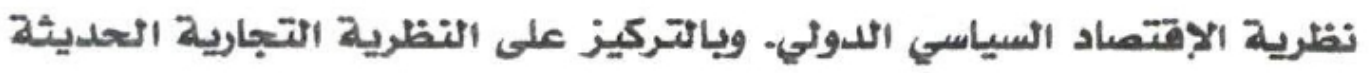
لإلاقتصاد السياسي الدولي، تقوم هذه الورقة البعثية بتقديم أطروحلة مفادها

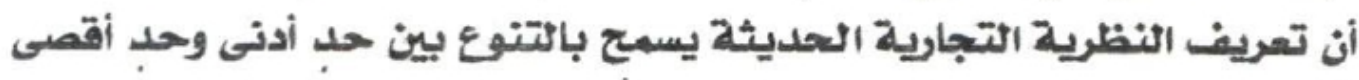
لتعريف هذه النظّرية، وتقوم الورقة أيضًا بطرح ما يمكن تسميته بانتظريلة

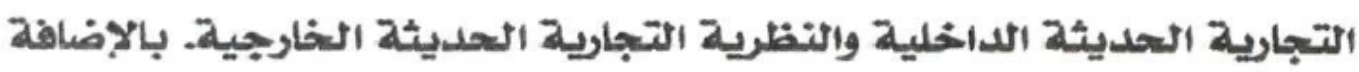
!لى هذا، فإن هذه الورقة البحثية تقدم أطروحة مفادها أن هذا التنوع فى تعريف

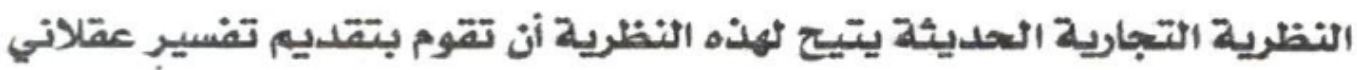

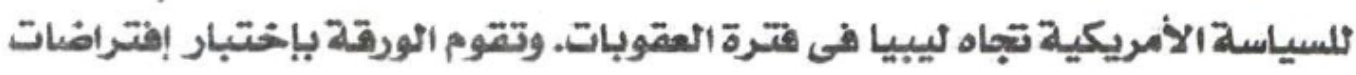

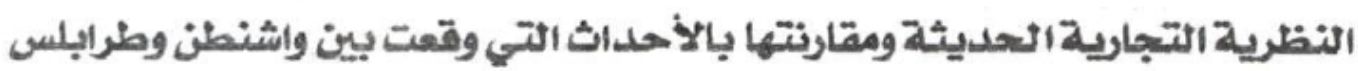

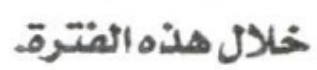

المصدلحات الأساسية، النظرية التجارية العحيثة، العقوبات الإقتمادية،

$$
\text { الولويات المتتحلة ليبيا }
$$

